\title{
INTEGRASI MEDIASI KASUS PERCERAIAN DALAM BERACARA DI PENGADILAN AGAMA
}

\author{
Muhammad Saifullah \\ IAIN Walisongo Semarang \\ e-mail: say_full2003@yahoo.com
}

\begin{abstract}
This research aims to determine the implementation of mediation in divorce cases in The Religion Court Semarang, the substance perspective for PerMA No. 1 of 2008 on Mediation Procedure in the Court, and the legal culture for citizen proposing their problem to the court. This study uses the non-doctrinal law approach that puts the law as "skin out system" or the study of the law in action and also uses doctrinal law approach as a "skin in the system" or the study of law in book, PeMA No. 1 of 2008. The next, the study analysis uses the theory of Lawrence M. Friedman in law enforcement, Lucy V. Kazt theory in the mediation process, and content analysis. The researcher concludes that the mediation in the Religious Courts has not been effective yet because the litigants do not want to make peace, the lack of knowledge about science mediation judge, Religious Court cases are overload and limited means. Besides the existing mediation has just been done in court by requirement in which the parties should attend, whereas this requirement sometimes becomes the mediation success constraints. That is why, the success of mediation must be supported by a legal culture that preceded the dissemination and socialization of justice of peace in the mediation process, prioritybased divorce amicably and based on culture and local wisdom.
\end{abstract}

Penelitian ini bertujuan untuk mengetahui implementasi mediasi kasus perceraian di PA Semarang, dimensi substansi PerMA No. 1 Tahun 2008 tentang Prosedur Mediasi di Pengadilan dan budaya hukum masyarakat yang mengajukan perkaranya di pengadilan. Penelitian ini menggunakan pendekatan hukum non doktrinal yang menempatkan hukum sebagai "skin out system" atau studi mengenai law in action mengenai interrelasi antara hukum dengan lembaga Peradilan Agama yang harus melaksanakan amanat PerMA No. 1 tahun 2008. Penelitian ini juga menggunakan pendekatan doktrinal sebagai suatu "skin in system" atau studi mengenai law in book yang berupa PerMA No. 1 tahun 2008. Adapun analisis dalam penelitian ini menggunakan teori Lawrence M. Friedman dalam penegakan hukum, teori Lucy V. Kazt dalam proses mediasi, dan content analysis. Penelitian ini menyimpulkan bahwa mediasi di Peradilan Agama belum efektif karena para pihak yang berperkara tidak mau berdamai, minimnya pengetahuan hakim tentang ilmu mediasi, overload-nya perkara dan sarana Pengadilan Agama yang terbatas. Di samping itu mediasi yang ada hanya dilakukan di Pengadilan dengan syarat hadirnya para pihakmenjadi kendala keberhasilan mediasi. Keberhasilan mediasi harus didukung oleh budaya hukum yang diawali desiminasi dan sosialisasi perdamaian dalam proses mediasi peradilan, mengutamakan perceraian secara damai serta berbasis budaya dan kearifan lokal.

Keywords: integrasi, mediasi, perceraian, PerMA

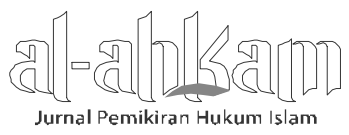




\section{Pendahuluan}

Penyelesaian masalah atau sengketa hukum harus dibangun dengan menggunakan paradigma baru, yaitu mengubah paradigma mengadili menjadi paradigma menyelesaikan sengketa hukum. Paradigma ini mencakup empat strategi pokok, yaitu: 1) revitalisasi fungsi pengadilan untuk mendamaikan pihak-pihak yang menghadapi sengketa hukum; 2) revitalisasi pranata-pranata sosial dengan memberikan dasardasar yang lebih kuat bagi pengembangan lembaga penyelesaian alternatif (Alternative Dispute Resolution/ADR);1 ${ }^{1}$ 3) menata kembali tata cara penyelesaian suatu perkara menjadi lebih efisien, efektif, produktif, dan mencerminkan keterpaduan sistem di antara unsur-unsur penegak hukum, dan 4) menata kembali hak-hak yang berperkara yang menyebabkan penyelesaian yang berlarut-larut dan mengundang potensi konflik "permanen" di antara pihak yang berkonflik. ${ }^{2}$

Revitalisasi pengadilan melalui perubahan paradigma di atas diwujudkan oleh Mahkamah Agung melalui penerbitan Peraturan Mahkamah Agung (selanjutnya ditulis PerMA) No. 1 Tahun 2008³. PerMA ini mengatur tentang integrasi mediasi ${ }^{4}$ ke dalam proses beracara di pengadilan, sehingga dikenal dengan Mediasi Peradilan (Court-Annexed Mediation). 5 Fenomena pengadilan menyelesaikan dengan cara mediasi, —disamping cara litigasi- merupakan pengembangan dunia hukum modern abad ke-20.

1Pengembangan lembaga Alternatif Penyelesaian Sengketa (APS) telah banyak dibentuk di Indonesia sejak PerMA No. 2 Tahun 2003 diterbitkan. Lembaga-lembaga tersebut antara lain: Pusat Mediasi Nasional (PMN) and Indonesian Institute for Conflict Transformation (IICT) di Jakarta, Walisongo Mediation Centre (WMC) Semarang Ambon Reconciliation and Mediation Centre (ARMC), Mataram Mediation Centre (MMC), Center of Alternative Dispute Resolution (CADRe) Salatiga, Center of Acceleration of Inter Religious and Ethnic Understanding (CAIREU) Pontianak, Center for Conflict Resolution and Peace Studies (CCRPS) Aceh, Asosiasi Mediator Indonesia (AMINDO), Badan Arbitrase Nasional Indonesia (BANI), BMN, Basyarnas, dan lain sebagainya.

2Bagir Manan, Sistem Peradilan Berwibawa (Yogyakarta: FH UII Press, 2005), h. 25.

3Sebelumnya (pada 11 September 2003) Mahkamah Agung telah menerbitkan PerMA No. 2 tahun 2003 tentang Prosedur Mediasi di Pengadilan Mahkamah Agung Republik Indonesia. PerMA ini kemudian direvisi melalui PerMA No.1 Tahun 2008.

${ }^{4}$ Mediasi berasal dari bahasa Latin 'Mediare' yang berarti berada di tengah. Makna ini menunjuk pada peran yang ditampilkan oleh pihak ketiga sebagai mediator dalam menjalankan tugasnya menengahi dan menyelesaikan sengketa antara para pihak. Menurut Pasal 1 ayat 7 Perma No. 1 tahun 2008, Mediasi adalah cara penyelesaian sengketa melalui proses perundingan untuk memperoleh kesepakatan para pihak dengan dibantu oleh mediator.

${ }^{5}$ Dalam ilmu mediasi, Intergrasi mediasi dalam sistem peradilan dikenal dengan beberapa istilah, antara lain; Court-Annexed Mediation, Court-Based Mediation dan Court-Integrated Mediation.

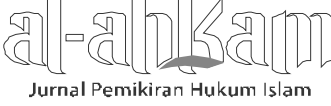


Berdasarkan beberapa evaluasi terhadap pelaksanaan mediasi di peradilan menunjukkan bahwa PerMA Mediasi ini sangat penting dalam upaya menyelesaikan sengketa (bukan memutus perkara). Harapan PerMA No. 1 Tahun 2008 tentang Prosedur Mediasi di Pengadilan Mahkamah Agung Republik Indonesia setidaknya meliputi 4 keinginan, yaitu: 1) mediasi proses penyelesaian sengketa diharapkan lebih cepat dan murah sesuai dengan harapan para pihak yang bersengketa; 2) mediasi lebih memberikan peluang kepada para pihak yang bersengketa untuk turut serta dalam menemukan penyelesaian yang memuaskan para pihak; 3) mediasi diharapkan dapat mengurangi penumpukan perkara di pengadilan, dan 4) mediasi akan memperkuat dan memaksimalkan fungsi lembaga pengadilan dalam menyelesaikan sengketa secara non ajudikatif.

Integrasi mediasi dalam perkara perceraian merupakan kajian yang cukup menarik karena dominasi perkara di Pengadilan Agama (Selanjutnya ditulis PA) memiliki peringkat tertinggi. Fenomena ini hampir terjadi di seluruh Pengadilan agama di Indonesia. ${ }^{6}$ PA Semarang merupakan pengadilan kelas 1a yang harus melaksanakan mediasi sesuai dengan PerMA No. 1 Tahun 2008. Perkara perceraian merupakan perkara perdata yang harus diselesaikan melalui mediasi terlebih dahulu. Putusan pengadilan yang tidak melalui jalur mediasi terlebih dahulu, maka putusannya dianggap batal demi hukum.

Pada tahun 2010 sampai 2012, gugatan perceraian yang didaftarkan di PA Semarang mencapai 7.852 perkara. Pada tahun 2010 sebanyak 2.367 perkara (92.60\%), tahun 2011 sebanyak 2.668 perkara (92.54\%), dan 2012 sebanyak 2.817 (92.84\%). Dari jumlah tersebut, hanya 6 (enam) perkara yang berhasil diselesaikan melalui cara mediasi. Data ini menunjukkan kurang efektifnya proses mediasi di PA. Pemilihan Pengadilan Agama Semarang sebagai lokasi penelitian dengan pertimbangan: 1) perkara perceraian di PA Semarang sebagai pengadilan kelas 1a cukup tinggi, kurang lebih dua ribu tiga ratus sampai dua ribu delapan ratus perkara pertahun; 2) Jawa Tengah merupakan peringkat ketiga perkara perceraian di Indonesia; 3) PA Semarang memiliki jumlah hakim yang cukup banyak (18 hakim); 4) model mediasi di PA di Indonesia hampir semuanya

\footnotetext{
${ }^{6}$ Lihat table 1 pada tulisan berikutnya.

${ }^{7}$ Gugatan perceraian yang didaftarkan di Pengadilan Agama Semarang pada tahun 2010 sebanyak 2.367 perkara (92.60 \%), tahun 2011 sebanyak 2.668 perkara (92.54\%), dan 2012 sebanyak 2.817 (92.84\%). Dari jumlah tersebut, rata-rata diatas 60\% beruapa cerai gugat, yakni inisiatif untuk perceraian dilakukan oleh pihak istri.
}

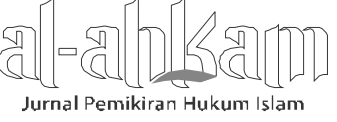


menerapkan sistem judicial mediator ${ }^{8}$, yaitu pelaksanaan mediasi yang menjadikan hakim sebagai aktor utama dalam penyelesaian sengketa, ${ }^{9}$ termasuk PA Semarang.

Tulisan yang berupa hasil penelitian ini akan mengkaji tentang: pertama, implementasi mediasi kasus perceraian di PA Semarang. Kedua, dimensi substansi PerMA No. 1 tahun 2008 tentang Prosedur Mediasi di Pengadilan Mahkamah Agung Republik Indonesia. Ketiga, budaya hukum masyarakat dalam implementasi mediasi perkara perceraian di PA.

\section{Implementasi Mediasi Kasus Perceraian di PA Semarang}

Jenis perkara yang paling banyak didaftarkan di PA Semarang adalah sengketa perkawinan. Berikut laporan perkara yang didaftarkan pada pengadilan tersebut untuk 3 (tiga) tahun terakhir, mulai tahun 2010 sampai 2012.

\section{Tabel 1.}

\section{Daftar Jenis Perkara yang Didaftarkan ke PA Semarang Tahun 2010-2012}

\begin{tabular}{clccc}
\hline No. & Jenis Perkara & $\mathbf{2 0 1 0}$ & $\mathbf{2 0 1 1}$ & $\mathbf{2 0 1 2}$ \\
\hline 1 & Cerai Talak & 806 & 848 & 873 \\
2 & Cerai Gugat & 1561 & 1820 & 1944 \\
3 & Penguasaan Anak & 8 & 7 & 6 \\
4 & Dispensasi Kawin & 52 & 60 & 81
\end{tabular}

\footnotetext{
8Disamping judicial mediator, dikenal juga model co mediation dan proffesional mediator. Co Mediation adalah mediasi pengadilan yang mengsinergikan dan mengkombinasikan keahlian yang dimiliki hakim dan kalangan professional (mediator non hakim). Dalam praktek mediasi model ini, penyelesaian dilakukan oleh lebih dari satu mediator yang memiliki keahlian berbeda sesuai dengan kasus yang ditanganinya. Di Jepang model ini di sebut chotei . Sedangkan professional mediator adalah mediasi pengadilan yang menempatkan kalangan preofesional (mediator non hakim) sebagai mediator. Kalangan professional ini dapat berasal dari unsur advokat, pekerja sosial, dosen, psikolog, atau pensiunan hakim. Model ini dilaksanakan di beberapa pengadilan di Amerika Serikat, Inggris dan Australia.

${ }^{9}$ Mediasi yudisial dilakukan sebelum proses litigasi, dan hakim berperan sebagai mediator. Model ini menjadi pilihan pelaksanaan mediasi di Indonesia karena para pihak tidak perlu membayar biaya tambahan jasa (tidak seperti memilih mediator non hakim), hakim dianggap memiliki pengalaman dan pengetahuan yang cukup dalam penyelesaian sengketa, wibawa dan otoritas yang dimiliki hakim dan efesiensi waktu karena hakim sudah melaksanakan PerMA Mediasi. Fatahillah A. Syukur, Mediasi Yudiassial di Indonesia Peluang dan Tantangan dalam memajukan Sistem Peradilan (Bandung: Mandar Maju, 2012), h. 23.
}

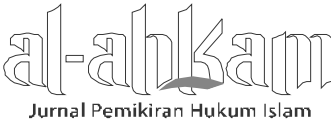


Integrasi Mediasi Kasus Perceraian dalam Beracara di Pengadilan Agama

\begin{tabular}{clccc}
5 & Ijin Poligami & 22 & 27 & 13 \\
6 & Perwalian & 32 & 27 & 37 \\
7 & Wali Adhol & 16 & 7 & 10 \\
8 & Kewarisan & 25 & 16 & 14 \\
9 & Harta Bersama & 8 & 12 & 12 \\
10 & Istbat Nikah & 7 & 8 & 12 \\
11 & Pengangkatan Anak & 1 & 0 & 0 \\
12 & Pembatalan perkawinan & 1 & 3 & 3 \\
13 & Penunjukan Orang & 0 & 1 & 0 \\
14 & Nafkah Anak oleh Ibu & 0 & 0 & 1 \\
15 & Lain-lain & 17 & 47 & 28 \\
\hline & & 2556 & 2883 & 3034 \\
\hline
\end{tabular}

Sumber: Laporan Perkara Tahunan di PA Semarang tahun 2010-2012.

Dari tabel $1 \mathrm{di}$ atas jumlah perkara yang didaftarkan di PA Semarang sebanyak 2.556 kasus. Data ini menunjukan bahwa rata-rata perbulan perkara yang diterima oleh PA Semarang mencapai 213 perbulan atau 10 perkara setiap harinya didaftarkan ke pengadilan.

Pada tahun 2011 PA Semarang menerima perkara sebanyak 2.883 kasus. Kenaikan angka dari tahun 2010 menunjukkan bahwa setiap bulan pengadilan tersebut menerima perkara 240 atau 11 perkara perhari. Dari jumlah 2.883 perkara, perkara perceraian mencapai 2.668 (92.54\%) dengan rincian cerai talak $848(29.41 \%)$ dan cerai gugat 1.820 (63.13\%).

Dibanding 2 (dua) tahun sebelumnya, kenaikan jumlah perkara terjadi pada tahun 2012. Dari tahun 2010 ke 2011 kenaikan perkara mencapai 327 kasus dan tahun 2013 mencapai 151 dari tahun 2012. Adapun perbandingan perkara perceraian dari tahun 2010 sampai 2012 menunjukkan bahwa tahun 2011 perkara perceraian naik 301 dari tahun sebelumnya dan pada tahun 2012 mencapai 149 kasus dari tahun 2011. Hal ini menunjukkan bahwa dalam kasus gugatan perceraian dari tahun ke tahun mengalami peningkatan. Perbandingan tersebut dapat dijelaskan dalam tabel berikut:

Tabel 2.

Perbandingan Kasus Gugat Talak dan Gugat Cerai di Pengadilan Agama

\begin{tabular}{|c|c|c|c|c|c|}
\hline \multirow{2}{*}{ No. } & Jenis & 2010 & 2011 & 2012 & \multirow{2}{*}{ Total } \\
\hline & Perkara & $\%$ & $\%$ & $\%$ & \\
\hline 1 & Cerai Talak & $31.53 \%$ & $29.41 \%$ & $28.77 \%$ & 2527 \\
\hline
\end{tabular}

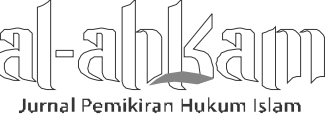


Muhammad Saifullah

\begin{tabular}{|c|c|c|c|c|c|c|c|c|}
\hline 2 & Cerai gugat & 1561 & $61.07 \%$ & 1820 & $63.13 \%$ & 1944 & $64.07 \%$ & 5325 \\
\hline & Jumlah & 2367 & $92.60 \%$ & 2668 & $92.54 \%$ & 2817 & $92.84 \%$ & 7852 \\
\hline
\end{tabular}

Sumber: Laporan Perkara Tahunan di PA Semarang tahun 2010-2012

Tabel 2 di atas menunjukkan bahwa kasus gugatan perceraian dari tahun ke tahun mengalami peningkatan secara umum. Namun jika dihubungkan dengan inisiatif pengajuan gugatan perceraian maka prosentase gugatan yang berupa cerai talak mengalami penurunan, yaitu $31.53 \%$ pada tahun 2010 menjadi $29.41 \%$ pada 2011, dan $28.77 \%$ pada 2012. Sedangkan cerai gugat mengalami kenaikan dari tahun ke tahun, yakni 2010 sebanyak 61.07\%, menjadi 63.13\% di tahun 2011, dan 2012 mengalami kenaikan menjadi 64.07\%.

Perkara gugatan perceraian di PA Semarang selama periode 2010 sampai 2012 mencapai 7.852 perkara. Gugatan tersebut terdiri atas 2.527 gugat talak dan 5.325 gugat cerai. Dari jumlah tersebut, penyelesaian perkara melalui mediasi hanya mencapai 6 (enam) perkara, yaitu tahun 2010 (1 perkara), 2011 (3 perkara), dan 2012 (3 perkara). Data ini menunjukkan bahwa keberhasilan mediasi pada 2010 hanya $0.050 \%$, tahun 2011 mencapai $0.133 \%$ dan tahun 2012 mencapai $0.10 \%$. Jika memperhatikan data ini maka dapat disimpulkan bahwa pelaksanaan PerMA No. 1 Tahun 2008 kurang efektif. Kurang efektifnya mediasi di Pengadilan Agama Semarang dipengaruhi oleh banyak faktor, baik internal maupun eksternal.

Proses mediasi di PA dilakukan sesuai dengan aturan PerMA No. 1 Tahun 2008. Namun dari proses tersebut ada beberapa hal yang kurang sesuai dengan aturan PerMA. Adapun faktor-faktor penghambat mediasi di PA meliputi beberapa hal sebagai berikut: pertama, para pihak tidak mau berdamai. Perkara yang didaftarkan ke luar pengadilan dapat dikategorikan menjadi dua: 1) Perkara yang sebelumnya telah dilakukan upaya mediasi dan yang belum dilakukan mediasi. Bagi perkara yang telah dilakukan mediasi sebelumnya, pendaftaran perkara ke PA merupakan cara akhir untuk menempuh perdamaian. Mediasi yang mereka lakukan pada umumnya difasilitasi oleh keluarga, tokoh agama tokoh masyarakat, atau perangkat desa/kelurahan setempat. Dengan didaftarkannya ke pengadilan, para pihak hanya ingin penyelesaian litigasi, untuk mengetahui siapa yang salah dan siapa yang benar. Bagi para penggugat, keberadaan mediasi di pengadilan dianggap tidak penting karena hanya mengulang mediasi sebelumnya. Sehingga mereka berpandangan bahwa jika memang pihak tergugat mau melakukan mediasi, harapannya sebelum perkara didaftarkan ke pengadilan, meskipun pada 
prinsipnya gugatan dapat dicabut kembali. Sementara bagi pihak tergugat dalam kasus perceraian berpandangan bahwa peluang untuk melakukan upaya damai masih terbuka. 2) Perkara yang sebelum didaftarkan ke pengadilan belum pernah dilakukan upaya mediasi sebelumnya. Bagi para pihak, khususnya pihak penggugat bahwa pengajuan gugatan perceraian ke pengadilan merupakan jalan akhir untuk menentukan siapa yang benar dan salah. Mereka berkeyakinan bahwa perceraian harus dilakukan, sehingga damai atau kembalinya hubungan antara suami istri tidak mungkin dilakukan. Keyakinan ini tampaknya sangat kuat bagi para pihak yang mengajukan gugatan, sehingga sulit untuk diselesaikan dengan cara mediasi.

Menurut Wahyudi, bahwa mengajak para pihak untuk berdamai sangat sulit karena menyangkut masalah perasaan dan batin. Hal ini berbeda dengan sengketa harta dimana penyelesaiannya cukup dengan membagi harta tersebut sesuai hasil kesepakatan para pihak. Sementara perkara perceraian tidak dapat disamakan dengan sengketa harta. Orang yang merasa tersakiti oleh pasangannya sulit untuk memberikan maaf dan jalan keluarnya adalah perceraian. ${ }^{10}$

Kedua, minimnya pengetahuan hakim mediator tentang ilmu mediasi. Faktor lain penghambat keberhasilan mediasi di PA Semarang adalah minimnya pengetahuan hakim mediator tentang ilmu mediasi. Hakim Pengadilan Agama Semarang sebanyak 18 hakim, dan hanya 3 (tiga) hakim yang pernah memperoleh pendidikan mediator, yaitu Drs. H. Ali Imron, SH., Drs. H. Toha Mansyur, SH., MH ${ }^{11}$ dan Dra. Hj. Ismiyati, $\mathrm{SH}$.

Dalam ilmu mediasi, seorang mediator profesional harus memperoleh pendidikan dan pelatihan dalam bidang mediasi. Jika ia melaksanakan tugas sebagai mediator, maka tugas tersebut tidak dapat dilaksanakan secara maksimal. Hal ini diakui oleh Drs. H. Wahyudi, SH., MSI, bahwa proses mediasi yang dilakukan oleh hakim mediator yang belum memperoleh sertifikat kurang maksimal dan perannya lebih dominan pada upaya menasehati para pihak yang bersengketa. ${ }^{12}$ 2013.

10Wawancara dengan Wahyudi (hakim/mediator Pengadilan Agama Semarang) pada tanggal 2 April

${ }^{11}$ Menurut Ketua Pengadilan Agama Semarang, tidak dicantumkannya Drs. H. Toha Mansyur, SH, MH. sebagai mediator karena kesibukan yang bersangkutan sebagai Wakil Ketua Pengadilan Agama Semarang. Meskipun demikian kadang yang bersangkutan juga melaksanakan tugas sebagai mediator. Wawancara dengan Drs.Jasiruddin, SH., MSI (Ketua Pengadilan Agama) Semarang pada 16 April 2013.

12Wawancara dengan Drs. H. Wahyudi, SH., MSI (Hakim PA Semarang) pada tanggal 2 April 2013.

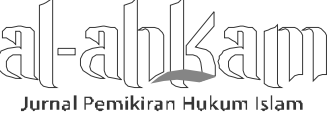


Ketiga, sarana pendukung mediasi. Pengadilan Agama Semarang telah menyediakan ruang mediasi yang khusus digunakan untuk proses sejak PerMA No. 1 Tahun 2008 diterbitkan oleh Mahkamah Agung. Berdasarkan PerMA Mediasi ini setiap pengadilan diwajibkan untuk menyelesaikan perkara perdata melalui mediasi terlebih dahulu, dan jika proses ini tidak dilalui maka putuhan hakim menjadi batal demi hukum. Ruang yang telah disiapkan oleh PA Semarang ini hanya digunakan untuk penyelesaian sengketa mediasi. Mengingat area Pengadilan yang sempit ruang mediasi dipindah ke ruang Wakil Ketua PA Semarang yang berdampingan dengan ruang hakim. Hal ini dilakukan karena PA Semarang menerima calon-calon hakim dari Mahkamah Agung sebanyak 8 (delapan) orang. ${ }^{13}$ Karena tidak ada tempat, calon-calon hakim tersebut menempati ruang mediasi dan ruang mediasi dipindahkan ke ruang wakil ketua.

Keempat, overload perkara. PA Semarang termasuk pengadilan yang memiliki penumpukan perkara yang cukup banyak. Pada setiap jam kerja, rata-rata perkara yang didaftarkan mencapai 12 (dua belas) perkara setiap hari. Sebagai contoh pada tahun 2012, PA Semarang menerima perkara sebanyak 3.034. Angka ini belum termasuk sisa perkara tahun sebelumnya yang mencapai 749 perkara. Yang diputus dalam tahun tersebut hanya 2.817. Dengan jumlah hakim 18 (delapan belas) orang dan 2 (dua) ruang sidang, maka sidang yang digelar di Pengadilan Agama Semarang berkisar antara 60 samai 70 kali sidang perhari. Beban berat ini menjadi penghambat proses mediasi karena dengan proses mediasi yang ketentuannya bisa dilakukan selama 40 (empat puluh) hari dan bisa diperpanjang/ditambah 14 (empat belas) hari justru bisa berakibat penumpukan perkara menjadi lebih besar.

Menurut Ketua PA Semarang, faktor perkara yang banyak ini menjadi salah satu penghambat pelaksanaan mediasi karena dengan diharuskannya proses mediasi sebelum proses litigasi akan menambah tugas hakim di pengadilan. Meskipun demikian hal ini bukan berarti PA Semarang mengabaikan proses mediasi. Proses mediasi tetap dilaksanakan, tetapi menurut pengamatannya proses mediasi kurang maksimal sehingga hampir semua perkara berlanjut pada sidang litigasi. ${ }^{14} \mathrm{Hal}$ ini bisa dilihat pada angka keberhasilan mediasi dari tahun 2010 sampai 2012 hanya mencapai 6 (enam) perkara.

\footnotetext{
13Para calon hakim yang berjumlah 8 (delapan) orang magang di Pengadilan Agama Semarang sejak 11 April 2011. Wawancara dengan Unung Sulistio Hadi, SHI (Calon Hakim pada Pengadilan Agama Semarang) pada 9 April 2013.

${ }^{14}$ Wawancara dengan Drs. Jasiruddin, SH., MSI (Ketua Pengadilan Agama Semarang pada 16 April 2013.
} 


\section{Dimensi Substansi PerMA No. 1 Tahun 2008 tentang Prosedur Mediasi di Pengadilan Mahkamah Agung Republik Indonesia}

Kelemahan pelaksanaan mediasi di pengadilan juga disebabkan beberapa aturan atau pasal PerMA yang kurang mendukung pelaksanaan mediasi secara ideal. Berdasarkan analisis penulis menunjukkan bahwa beberapa pasal dalam PerMA No. 1 Tahun 2008 memiliki kelemahan. Penjelasan kelemahan tersebut sebagai berikut:

Pertama, mediasi Pengadilan hanya untuk perkara yang diproses di pengadilan. Pasal 2 ayat 1 PerMA No. 1 Tahun 2008 menyebutkan: "Peraturan Mahkamah Agung ini hanya berlaku untuk mediasi yang terkait dengan proses berperkara di Pengadilan". Pasal ini mengandung arti bahwa berlakunya aturan dalam PerMA Mediasi hanya berlaku bagi sengketa yang telah terdaftar menjadi perkara saja di pengadilan, atau setidak-tidaknya sudah terdaftar sebagai perkara. Makna "proses berperkara di pengadilan" mengandung arti terbatas, yaitu suatu sengketa yang telah diajukan dan didaftarkan pada register pengadilan. Pasal 2 ayat 1 di atas mencerminkan kontradiksi dengan Pasal 23 ayat 1 yang menyebutkan: "Para pihak dengan bantuan mediator besertifikat yang berhasil menyelesaikan sengketa di luar pengadilan dengan kesepakatan perdamaian dapat mengajukan kesepakatan perdamaian tersebut ke pengadilan yang berwenang untuk memperoleh akta perdamaian dengan cara mengajukan gugatan."

Pasal di atas memberikan peluang penyelesaian perkara di luar pengadilan untuk dimintakan akte perdamaian ke pengadilan. Di luar pengadilan ini menunjuk pada mediasi yang tidak terkait langsung dengan proses mediasi menurut ketentuan PerMA Mediasi, bukan pelaksanaan mediasi di luar pengadilan karena para pihak memilih mediator non hakim. Jika yang dimaksudkan Mahkamah Agung adalah ketentuan yang dimuat dalam Pasal 23 ayat 1 maka redaksi pasal tersebut perlu dirubah menjadi: "Peraturan Mahkamah Agung ini hanya berlaku untuk mediasi yang terkait dengan proses berperkara dan yang diajukan menjadi perkara di pengadilan". Jika rumusan kalimat Pasal ayat 1 seperti di atas, maka maksud PerMA dapat terpenuhi dan dapat menjangkau dua pengertian proses mediasi, yaitu mediasi yang dilakukan setelah adanya perkara gugatan pengadilan dan mediasi yang telah selesai dilakukan di luar pengadilan, kemudian diajukan ke pengadilan untuk memperoleh akta perdamaian.

Hasil kesepakatan mediasi yang dilakukan di luar proses pengadilan untuk didaftarkan ke pengadilan dilakukan dengan cara mengajukan gugatan ke peng- 
adilan dengan melampirkan hasil kesepakatan perdamaian dan dokumen-dokumen yang membuktikan ada hubungan hukum para pihak dengan objek sengketa. Adapun isi kesepakatan perdamaian harus memenuhi persyaratan, antara lain: sesuai kehendak para pihak, tidak bertentangan dengan hukum, tidak merugikan pihak ketiga, dapat dieksekusi, dan beriktikad baik.

Kedua, profesionalisasi mediator melalui sertifikat mediator. Pasal 5 ayat 1 PerMA Mediasi menyatakan bahwa seseorang mediator yang melaksanakan tugas dan fungsi mediator di pengadilan pada asasnya wajib memiliki sertifikat mediator yang diperoleh setelah mengikuti pelatihan yang diselenggarakan oleh lembaga yang telah memperoleh akreditasi dari Mahkamah Agung Republik Indonesia. Siapapun bisa menjadi mediator asal ia sudah memiliki sertifikat sebagai mediator. Namun Pasal 5 ayat 2 menegaskan bahwa hakim dapat menjadi mediator meskipun belum memiliki sertifikat sebagai mediator, jika dalam wilayah pengadilan tidak ada hakim yang bersertifikat mediator. Pasal ini menjelaskan bahwa semua hakim dapat menjadi mediator meskipun belum mengikuti pelatihan mediasi dan memperoleh sertifikat sebagai mediator dari lembaga yang telah terakreditasi oleh Mahkamah Agung. Hal ini menyebabkan mediasi lebih banyak dilakukan oleh orang yang belum memiliki skil dalam bidang mediasi.

Pelatihan mediasi bagi hakim bukan hanya sekedar tuntutan formalitas saja, namun lebih ditekankan bagaimana para hakim-hakim mediator mampu memfasilitasi para pihak bersengketa, bukan memberikan nasehat untuk damai, atau memohon para pihak melakukan upaya damai dan selanjutnya melaporkan kepada hakim mediator. Sehingga pembekalan teori dan praktek mediasi bagi hakim turut serta dalam menentukan keberhasilan mediasi. Pelatihan untuk memperoleh sertifikat mediator telah diupayakan oleh Mahkamah Agung agar semua hakim memperoleh pendidikan dan pelatihan mediasi. Mengingat jumlah hakim di Indonesia sangat banyak, maka pelaksanaan pelatihan mediasi dilakukan secara periodik dan bertahap. Bahkan Mahkamah Agung juga menginisiasi pelatihan mediasi bagi calon-calon hakim di Indonesia, agar ketika mereka menjadi hakim sudah memiliki skil dan kemampuan memfasilitasi proses mediasi. Mediator pada setiap pengadilan berasal dari kalangan hakim dan bukan hakim yang telah memiliki sertifikat sebagai mediator". Namun hingga sekarang (setelah 9 tahun lebih) belum semuanya hakim di beberapa lembaga peradilan memperoleh pelatihan mediasi. Oleh karenanya Pasal 5 ayat 2 PerMA No. 1 Tahun 2008 yang menegaskan bahwa hakim dapat menjadi mediator meskipun belum memiliki

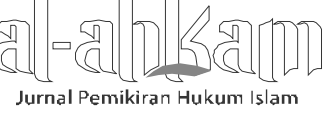


sertifikat sebagai mediator harus dirubah menjadi setiap hakim yang melaksanakan proses mediasi harus sudah memiliki sertifikat mediasi, sehingga hakim yang belum memiliki sertifikat mediasi hanya menyelesaiakan perkara dengan cara litigasi. Demikian juga Mahkamah Agung harus mewajibkan hakim yang belum memperoleh pelatihan mediasi wajib mengikuti pelatihan ini atas biaya pengadilan atau yang bersangkutan. Hakim harus diwajibkan untuk mengikuti pelatihan ini mengingat PerMA Mediasi sudah berlangsung cukup lama sementara pelaksana mediasi bukan dilakukan oleh orang yang ahli dalam bidang mediasi.

Ketiga, syarat kehadiran para pihak. Proses mediasi yang dilakukan oleh para pihak yang bersengketa, pada prinsipnya tidak bisa diwakilkan kepada pihak lain. Memberikan kuasa hukum kepada pihak lain dalam proses mediasi jauh dari makna dan filosofi pentingnya mediasi dilakukan oleh pihak-pihak terkait. Jika ini dikaitkan dengan ilmu mediasi, maka pihak yang menerima kuasa hukum "tidak akan mampu" sepenuhnya mewakili dari apa yang dirasakan oleh para pihak, khususnya dalam penggalian interest. ${ }^{15}$

PerMA No. 1 tahun 2008 tidak mengatur tentang keharusan pihak yang bersengketa untuk maju sendiri dalam proses mediasi. Kehadiran langsung oleh para pihak yang bersengketa dalam proses mediasi hanya bersifat anjuran saja, sebagaimana Pasal 15 ayat 2: "Mediator wajib mendorong para pihak untuk secara langsung berperan dalam proses mediasi". Tafsir atas kebolehan para pihak yang bersengketa untuk tidak hadir dalam proses mediasi, atau mewakilkan kepada pihak lain dapat dipahami dari beberapa pasal yang dimuat dalam PerMA Mediasi. Penafsiran atas kebolehan mewakilkan atau memberikan kuasa hukum dimuat dalam 3 (tiga) pasal yang menyebut istilah "kuasa hukum".16

\footnotetext{
15Dalam ilmu mediasi, interest adalah what you want but you don't say. Sering penyelesaian sengketa berbasis pada posisi, sehingga penyelesaiannya berebut pada posisi itu sendiri. Seharusnya penyelesaian sengketa berbasis pada interest. Mediator dalam memfasilitasi para pihak yang bersengketa harus memiliki seni dan ketrampilan menggali interest para pihak. Penggalian interest hanya bisa dilakukan oleh yang bersangkutan. Jika ini diwakilkan kepada pihak lain, maka penggalian interest tidak akan tercapai secara maksimal, mengingat emosi dan perasaan sangat berbeda dirasakan langsung oleh pihak yang bersengketa, dan kuasa hukum hanya berempati saja, atau dengan bahasa lain: apa yang dirasakan oleh orang yang bersengketa, penjiwaannya berbeda dengan advokat, meskipun ia sudah menerima kuasa hukum dan permasalahannya.

16Tiga pasal di atas berbunyi: Mediator berkewajiban menyatakan mediasi telah gagal jika salah satu.pihak atau para pihak atau kuasa hukumnya telah dua kali berturut-turut tidak menghadiri pertemuan mediasi sesuai jadwal pertemuan mediasi yang telah disepakati atau telah dua kali berturut-turut tidak menghadiri pertemuan mediasi tanpa alasan setelah dipanggil secara patut (ps
} 
Pasal 14 mengisyaratkan bahwa para pihak yang bersengketa dapat memberikan kuasa hukum kepada pihak lain (advokat) untuk mewakili proses mediasi. Sebagai orang yang bertindak atas nama klien, advokat memiliki kekuasaan yang cukup banyak, seperti ia berhak untuk memberikan persetujuan atau tidak kepada mediator untuk mengundang seorang atau lebih ahli dalam bidang yang terkait dengan sengketa. Namun kekuasaan advokat tidak sampai pada persetujuan secara langsung atas kesepakatan damai yang telah dicapai.

Dalam kasus perceraian, apa yang disampaikan oleh kuasa hukum (advokat) tentu tidak akan mampu menyampaikan apa yang dirasakan kliennya, atau pihak yang bersengketa. Perkara perceraian adalah perkara yang lebih dominan berkaitan dengan perasaan. Dalam KHI disebutkan bahwa pernikahan adalah hubungan yang sangat kuat (mithāqan ghalizan) antara kedua mempelai atau calon pengantin. Hubungan yang sangat kuat ini diwujudkan dengan ikatan batin antara suami dan istri. Karena itu mediasi yang diwakili oleh advokat, para pihak diharuskan membuat pernyataan secara tertulis jika terjadi perdamaian (Pasal 17 ayat 2). Sebaliknya, jika para pihak tidak membuat persetujuan atas kesepakatan yang dicapai, maka hasil perdamaian yang dilakukan oleh para advokat tidak ada manfaatnya.

Keempat, honorarium mediator. Pelaksanaan mediasi di pengadilan dilaksanakan oleh mediator dari unsur hakim maupun non hakim. Penyebutan mediator non hakim menunjuk pada nama-nama mediator yang bertugas di pengadilan setempat dan ditunjuk oleh ketua pengadilan yang dicantumkan di kantor-kantor pengadilan. Klasifikasi asal mediator sebagaimana penjelasan di atas berimplikasi pada biaya mediasi. Pasal 10 PerMA Mediasi mengatur tentang honorarium mediator. Bunyi pasal tersebut adalah: 1) Penggunaan jasa mediator hakim tidak dipungut biaya; 2) Uang jasa mediator bukan hakim ditanggung bersama oleh para pihak atau berdasarkan kesepakatan para pihak.

Pada prinsipnya para pihak yang bersengketa memiliki kebebasan untuk memilih mediator yang nama-nama mediatornya tercantum pada kantor-kantor pengadilan. Mereka diberi waktu sampai 2 (dua) hari untuk memilih mediator berdasarkan hasil kesepakatan para pihak. Memilih mediator bagi pihak-pihak

14 ayat 1); Atas persetujuan para pihak atau kuasa hukum, mediator dapat mengundang seorang atau lebih ahli dalam bidang tertentu untuk memberikan penjelasan atau pertimbangan yang dapat membantu menyelesaikan perbedaan pendapat di antara para pihak. (Pasal 16 ayat 1); "Jika dalam proses mediasi para pihak diwakili oleh kuasa hukum, para pihak wajib menyatakan secara tertulis persetujuan atas kesepakatan yang dicapai (17 ayat 2).

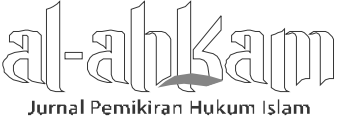


yang bersengketa tidaklah sederhana karena membutuhkan komunikasi antara pihak dan pemilihan mediator non hakim berimplikasi pada biaya yang harus dikeluarkan. Jika para pihak memilih mediator non hakim maka mereka harus menanggung biaya mediator berdasarkan kesepakatan para pihak. Atas dasar pertimbangan ini maka para pihak yang bersengketa lebih memilih mediator dari unsur hakim.

Pasal 10 ayat 2 yang memberikan kesan bahwa uang jasa (honor) bagi mediator seakan-akan mahal seperti jasa bagi advokat, sebaiknya di hilangkan. Jika dibandingkan antara profesi mediator dengan advokat memiliki tugas dan fungsi yang berbeda. Tugas mediator lebih ringan karena ia hanya sebagai fasilitator bagi para pihak yang bersengketa dan ia memposisikan dirinya sebagai seorang yang netral. Sedangkan profesi advokat dalam menjalankan tugasnya ia harus membela kliennya, dan memposisikan dirinya untuk melawan pihak lain dalam persidangan. Pembelaan terhadap klien ini dilakukan dengan membuat surat gugatan, membuat replik atau duplik, berusaha untuk menghadirkan para saksi, dan ia berusaha keras agar menjadi pihak yang menang. Sehingga wajar jika biaya advokat lebih mahal dibanding dengan mediator.

\section{Budaya Hukum Masyarakat dalam Implementasi Mediasi Perkara Perceraian di Pengadilan Agama}

Keberhasilan mediasi peradilan tidak cukup hanya didukung oleh aturanaturan tentang mediasi dan pelaksana mediasi yang profesional, namun juga membutuhkan kesadaran masyarakat tentang makna perdamaian dalam kehidupan, atau meminjam istilah Lawrence M. Friedman disebut budaya hukum. Budaya hukum adalah kesadaran masyarakat tentang kepatuhan terhadap aturan-aturan hukum yang dibangun atas pondasi pemahaman terhadap pentingnya perdamaian. Damai dan konflik adalah fitrah manusia. Setiap manusia menginginkan hidup damai dengan siapapun. Meskipun demikian, kadang muncul konflik di tengah masyarakat. Kehadiran konflik dalam masyarakat adalah fitrah atau sunnatullāh.

Keberhasilan mediasi ini harus didukung oleh budaya hukum masyarakat, di samping struktur dan substansi hukum. Untuk membangun budaya hukum dalam kasus perceraian dengan cara damai di pengadilan dapat di tempuh melalui tiga cara sebagai berikut: pertama, PerMA Mediasi mengatur bagaimana proses mediasi peradilan diselenggarakan. Tahapan-tahapan dalam proses mediasi secara

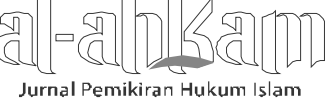


jelas diuraikan dalam pasal demi pasal. Karena itu, maka mediasi harus diperkenalkan kepada para pihak yang bersengketa. Setelah penggugat mendaftarkan gugatannya, pengadilan memanggil para pihak untuk hadir dalam sidang pertama. Pada sidang pertama ini, hakim mewajibkan para pihak untuk menempuh mediasi. ${ }^{17}$ Selanjutnya para pihak memilih mediator yang disepakati. Jika ia memilih mediator hakim, biasanya langsung dilanjutkan proses mediasi di ruang mediasi. ${ }^{18}$ Namun jika memilih mediator non hakim, biasanya mediasi dilaksanakan di lain hari.

Agar mediasi dikenal oleh para pihak mediator harus selalu menjelaskan pentingnya perdamaian dalam segala penyelesaian konflik. Hal ini dapat dilakukan dengan beberapa cara sebagai berikut: 1) Arti penting mediasi. Ketrampilan mediator menjelaskan tentang mediasi, sebagai bagian dari proses yang harus dilalui dalam proses beracara di pengadilan, merupakan kunci awal menuju keberhasilan mediasi. Hakikat mediasi adalah perdamaian, dan mencapai perdamaian bukanlah sesuatu yang mudah. Karena itu musyawarah melalui mediasi perlu difasilitasi oleh pihak ketiga, yaitu mediator. Ia harus bersikap netral dan imparsial. Para pihak adalah para pembuat keputusan, dan keputusan terbaik adalah damai. Proses mediasi memberikan akses yang seluas-luasnya kepada para pihak perlu ditegaskan oleh mediator, agar para pihak menyadari masalah yang sedang mereka alami akan lebih baik jika para pihak yang menyelesaikan masalahnya sendiri, tidak perlu melibatkan hakim. Mediator dapat memberikan beberapa contoh, dimana perjanjian-perjanjian, berita acara kesepahaman (MoU) dalam hal tertentu selalu mencantumkan pasal dimana jika terjadi perselisihan maka perselisihan tersebut diselesaikan melalui mediasi. Pesan moral ini akan menyadarkan para pihak untuk menyelesaikan masalahnya dengan cara damai serta terjalinnya hubungan baik para pihak. Kelebihan mediasi dibanding litigasi; integrasi mediasi dalam dalam bercara di pengadilan menunjukkan bahwa pengadilan melakukan dua cara penyelesaian sengketa. Penyelesaian sengketa perdata harus dilalui dengan cara mediasi. Di hadapan para pihak yang bersengketa, seorang mediator harus menjelaskan kelebihan mediasi dibanding litigasi. Kelebihan mediasi ini meliputi mediasi bisa menghemat waktu dan biaya,

\footnotetext{
17Pasal 7 PerMA No. 1 Tahun 2008.

18Terkecuali pengadilan yang telah memiliki ruang khusus bagi mediator non hakim dan ruang mediasi yang cukup, sehingga pada hari yang sama setelah sidang pertama, mediasi dapat dilaksanakan.
} 
Mediasi dapat meningkatkan komunikasi, mediasi dapat mengurangi beban emosional para pihak karena para pihak memiliki kontrol terhadap outcome. 2) Sesuatu yang boleh dan tidak boleh dilakukan dalam proses mediasi. Pesan mediator kepada para pihak dalam negosiasi agar menjaga etika berbicara, menggunakan pilihan kata yang baik dan benar, dan volume suara yang cukup. Ketika salah satu pihak berbicara maka pihak lain harus mendengarkan dengan baik agar pesan dapat diterima dengan baik dan benar. Ketika berbicara menggunakan katakata yang baik agar tidak melukai atau menyinggung pihak lain. Tidak dibenarkan seseorang yang akan melakukan upaya damai, justru prosesnya menyebabkan eskalasi konflik menjadi lebih tinggi. Demikian juga, dalam berbicara cukup menggunakan volume suara yang tidak tinggi, cukup bisa di dengar oleh orangorang yang berada dalam runag mediasi.

Kedua, membangun budaya damai dalam konflik rumah tangga; Islam mengenal dua jenis konflik rumah tangga yang disebut dalam ajaran Islam dengan istilah nushūz dan shiqāq. Nushūz adalah ketidakpatuhan antara seorang istri terhadap suaminya atau sebaliknya. Kesalahan nushūz terletak pada salah satu pihak, sehingga dapat diketahui siapa yang salah. Kesalahan ini harus diperbaiki agar tidak semakin komplek dan menjadi konflik shiqāq. Shiqāq adalah konflik yang sudah kompleks yang sulit diketahui siapa yang salah dan siapa yang benar. Jika mereka menuduh pihak lain salah, pihak lain akan menuduh sebaliknya. Karena itu, jenis konflik ini harus diselesaikan dengan melibatkan pihak ketika yang disebut hākam. Kedua konflik ini bisa menyebabkan perceraian jika tidak segera diselesaikan.

Islam mengajarkan kepada umatnya ketika tersandung masalah nushūz dilakukan dengan cara-cara yang diajarkan dalam syari'ah. Ajaran syari'ah ini merupakan kewajiban yang harus ditradisikan karena bersumber dari sumber hukum yang paling tinggi, yaitu al-Qur'an surat 34. Penyelesaian nushūz dilakukan melalui tiga tahap, yaitu menasehati pihak yang melakukan nushūz, pisah ranjang, dan memukul yang tidak menyakitkan. Demikian juga dalam shiqãq, al-Quran mengajarkan bagaimana penyelesaian konflik rumat tangga tersebut. Al-Qur'an surat al-Nisā' ayat 35 mewajibkan menyelesaikan masalah tersebut melalui pihak ketiga yang disebut hăkam. Ia adalah utusan dari pihak suami dan pihak istri yang membantu para pihak karena penyelesaian tidak cukup diselesaiakan hanya oleh suami dan istri.

Ketiga, membangun budaya damai melalui kearifan lokal. Masyarakat Indonesia memiliki kecenderungan menyelesaikan masalahnya melalui hukum

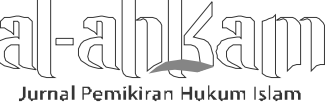


adat atau tradisi yang turun temurun. Hukum adat sebagai suatu sistem hukum memiliki pola sendiri dalam menyelesaikan sengketa. Hukum adat memiliki karakter yang khas dan unik apabila dibandingkan dengan sistem hukum lain. Ia lahir dan tumbuh dari masyarakat, sehingga keberadaannya bersenyawa dan tidak dapat dipisahkan dari masyarakat. ${ }^{19}$ Hukum adat merupakan wujud yuris fenomenologis dari masyarakat hukum adat. Adat masyarakat untuk menyelesaikan masalahnya sangat variatif berdasarkan daerah masing-masing. Setiap daerah memiliki kearifan lokal20 dalam merespon masalah yang dihadapinya.

Kearifan lokal tidaklah sama antara satu tempat dengan tempat lain. Perbedaan ini disebabkan oleh tantangan alam dan kebutuhan hidupnya berbedabeda, sehingga pengalamannya dalam memenuhi kebutuhan hidupnya memunculkan berbagai sistem pengetahuan baik yang berhubungan dengan lingkungan maupun sosial. Sebagai salah satu bentuk perilaku manusia, kearifan lokal bukanlah suatu hal yang statis melainkan berubah sejalan dengan waktu, tergantung dari tatanan dan ikatan sosial budaya yang ada di masyarakat. Kearifan lokal dalam membangun budaya damai memiliki kontribusi besar bagi upaya penyelesaian sengketa di Indonesia. Upaya ini sejalan dengan PerMA No. 1 Tahun 2008 yang mengharuskan setiap sengketa perdata harus diselesaikan dengan cara mediasi. Inti penyelesaian mediasi adalah kesepakatan damai antara para pihak. Karena itu seharusnya mediasi di pengadilan mudah untuk dicapai. Namun faktanya sebaliknya dimana para pihak kadang berketetapan hati tidak mau menempuh jalur mediasi.

Menurut para hakim Pengadilan Agama Kelas 1a Semarang bahwa para penggugat yang mengajukan gugat talak maupun gugat cerai mayoritas tidak mau didamaikan. Sikap 'pokoke' menyulitkan mediator untuk melajutkan proses mediasi, karena mediasi dapat berlangsung atas kesepakatan para pihak menempuh upaya damai. Rendahnya masyarakat dalam merespon upaya damai melalui mediasi salah satunya disebabkan karena masyarakat sudah mulai meninggalkan tradisi-tradisinya yang merupakan bagian dari kearifan lokal.

\footnotetext{
${ }^{19}$ Syahrizal Abbas, Mediasi dalam Perspektif Hukum Syari'ah, Hukum Adat, dan Hukum Nasional (Jakarta: Kencana Prenada Media Group, 2009), h. 235

${ }^{20}$ Kearifan lokal adalah semua bentuk pengetahuan, keyakinan, pemahaman atau wawasan serta adat kebiasaan atau etika yang menuntun perilaku manusia dalam kehidupan di dalam komunitas ekologis. Semua bentuk kearifan lokal ini dihayati, dipraktekkan, diajarkan dan diwariskan dari generasi ke generasi sekaligus membentuk pola perilaku manusia terhadap sesama manusia.
} 
Penyelesaian sengketa rumah tangga yang dahulunya diselesaiakan terlebih dahulu melalui tokoh agama, tokoh masyarakat, keluarga dekat, dan BP4 sudah mulai ditinggalkan. Tokoh agama dan tokoh masyarakat yang pada umumnya menjadi petugas di BP4, kini ia sudah tidak memiliki peran yang dulu bermanfaat. Pihak yang akan bercerai harus datang ke BP4 untuk diselesaikan, selama tidak ada keterangan bahwa yang bersangkutan sudah melakukan upaya damai di BP4, maka pengadilan tidak akan menyidangkan perkaranya.

Pada masyarakat Jawa dikenal pitutur luhur (kata-kata bijak). Pitutur luhur diperoleh dari leluhur mereka yang mengajarkan nilai-nilai kehidupan tentang bagaimana bersikap sesama manusia maupun perlakuan terhadap alam. Idiom jawa ono rembug yo dirembug mengajarkan kepada masyarakat jawa untuk selalu bermusyawarah atas masalah yang muncul. Melalui musyawarah diperoleh kesepakan mufakat sehingga memuaskan para pihak agar tidak ada yang merasa kalah. Cara ini akan memelihara tali persahabatan dan kerukunan masyarakat yang dikenal dalam filsafat jawa rukun agawe santosa, crah agawe bubrah yang berarti kerukunan menumbuhkan kekuatan, perpecahan menumbuhkan kerusakan.

Untuk membina kerukunan dan hidup damai, masyarakat Jawa memegang teguh falsafah ibu bumi, bapa aksa (ibu adalah bumi, bapak adalah langit). Maksud falsafah ini, bumi adalah simbol ibu yang memberikan kesuburan tanah sebagai tempat kegiatan pertanian. Langit adalah simbol bapak yang memberikan keberkahan lewat hujan. Ajaran ini mengajarkan kepada manusia agar saling menyayangi, melindungi, dan menghormati bumi beserta langit sebagaimana seorang anak melakukannya kepada kedua orang tuanya. Jika kita merusak bumi, maka langit pun akan ikut marah. Seperti halnya jika kita berbuat tidak baik kepada ibu, maka bapak pun akan marah, demikian pula sebaliknya.

Membangun budaya masyarakat melalui local wisdom dilakukan dengan memegang teguh tradisi penyelesaian perkara berdasarkan adat daerah masingmasing, seperti runggun ${ }^{21}$ Upaya damai dalam penyelesaian sengketa juga dilakukan oleh masyarakat Banjar dengan istilah Adat Badamai, ${ }^{22}$ yaitu proses pe-

\footnotetext{
${ }^{21}$ Runggun adalah bersidang atau berunding dengan cara musyawarah antara pihak-pihak yang bersengketa untuk mencapai kata mufakat yang dihadiri oleh sangkep sitelu pada mayarakat Batak Karo. Mediator penyelesaian sengketa ini dilakukan oleh jasa anak beru, seninan, kalibumbu. Penyelesaian melalui runggun ini dipandang efektif karena tidak membutuhkan waktu lama, tidak berbelit-belit, murah, kekeluargaan, harmonis, dan merupakan akar budaya lokal.
}

${ }^{22}$ Adat Badamai juga dikenal dengan beberapa istilah, antara lain babaikan, baparbaik, bapatut atau mamtut, dan baakuran.

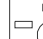

Jurnal Pemikiran Hukum Islam 
rembukan atau musyawarah dalam pembahasan bersama dengan maksud untuk mencapai kesepakatan. Adat Badamai dilakukan agar tidak terjadi persengketaan yang membahayakan bagi tatanan sosial masyarakat. Penyelesaian melalui adat ini meliputi perkara perdata dan pidana. Tradisi Adat Badamai yang esensinya adalah penyelesaian dengan mufakat telah diadopsi dalam Undang-undang Sultan Adam Pasal 21 yang berbunyi:

“Tiap kampung kalau ada perbantahan isi kampungnja ija itu tetuha kampungnja kusuruhkan membitjarakan mupakat-mupakat lawan jang tuhatuha kampungnja itu lamun tiada djuga dapat membitjarakan ikam bawa kepada hakim" (tiap-tiap kampung bilamana terjadi sengketa, maka diperintahkan untuk mendamaikan (mamatut) dengan tetuha kampung, bilamana tidak berhasil barulah dibawa kepada hakim). ${ }^{23}$

Desa Adat di Bali juga memiliki kekuasaan yang dijelmakan dalam sangkepan (rapat). Sangkepan adalah rapat desa adat yang membahas masalah-masalah tertentu dengan cara musyawarah. Sengketa yang dimusyawarahkan ini hanya mencakup sengketa perdata dan kasus pidana, dan dimungkinkan adanya sanksi yang diberikan kepada pelaku berdasarkan kesepakatan. Meskipun demikian untuk kasus pidana bersifat optional, kadang diselesaikan melalui sangkepan atau Pengadilan Negeri.

Kearifan lokal penyelesaian sengketa di Aceh dikenal dengan istilah Dong teungoh. Dong Teungoh artinya penengah, yakni tokoh adat atau tokoh masyarakat yang memfasilitasi para pihak yang bersengketa. Penyelesaian ini relatif lebih cepat dan biaya murah. Namun penyelesaian melalui dong teungoh belum dapat mencerminkan keadilan karena para mediatornya kurang mampu bersikap netral dan imparsial. Pengaruh dan mempengaruhi para pihak yang bersengketa menimbulkan hasil kesepakatan yang kurang seimbang. 24

Pada masyarakat sasak di Lombok Barat, penyelesaian sengketa dilakukan melalui lembaga kerama gubuk. Kerama gubuk adalah institusi adat yang beranggotakan orang atau kelompok yang memiliki pengaruh secara sosial. Mereka yang duduk dalam kerama gubuk adalah kombinasi pimpinan formal dan non

\footnotetext{
${ }^{23}$ Ahmadi Hasan, "Penyelesaian Sengketa Melalui Upaya (Non Litigasi) Menurut Peraturan Perundang-undangan”, Jurnal al-Banjari, Vol. 5 No. 9, Januari - Juni 2007.

24 Yayah Yarotul Salamah, "Mediasi dalam Proses Beracara di Pengadilan: Studi Mengenai Mediasi di Pengadilan Negeri Proyek Percontohan Mahkamah Agung RI.", Disertasi pada Fakultas Hukum Universitas Indonesia, 2009, h. 29-30.
}

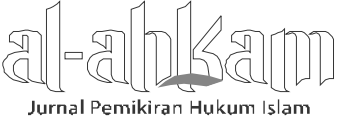


formal. Jajaran pimpinan formal adalah kepala pemerintahan kampung dan perangkatnya, sedangkan unsur pimpinan non formal adalah para tokoh agama/ penghulu dan pemuka adat. Masalah yang dimusyawarahkan biasanya berkenaan dengan kasus-kasus adat pelanggaran adat merari, perzinahan, warisan dan pelanggaran adat lainnya.

Membangun budaya damai melalui kearifan lokal sebagaimana penjelasan di atas memiliki kontribusi mendukung berjalannya sistem hukum. Aturan yang baik (substance) dan pelaksana (structure) yang profesional tidak cukup menjadi modal pelaksanaan mediasi di peradilan sesuai impian Mahkamah Agung. Karena itu, budaya hukum (legal culture) masyarakat yang cinta damai sesuai dengan kearifan lokal akan menempatkan masyarakat memiliki saling pengertian untuk mencapai kepentingan (interest) bersama. Jika kesadaran masyarakat sudah terbangun, maka penyelesaian masalah (sengketa) tidak bermuara pada posisi, namun lebih pada penggalian terhadap hal-hal yang menyebabkan seseorang menuntut posisi, sehingga hasil kesepakatan dapat memuaskan para pihak (win-win solution).

\section{Kesimpulan}

Peraturan Mahkamah Agung (PerMA) No. 1 Tahun 2008 tentang Prosedur Mediasi di Pengadilan Mahkamah Agung Republik Indonesia merupakan integrasi mediasi dalam sistem penyelesaian perkara di lembaga peradilan. Integrasi ini dimaksudkan untuk mengurangi jumlah penumpukan perkara (court congestion), memberikan akses yang luas kepada para pihak untuk turut serta dalam menyelesaikan masalahnya sendiri, dan memberikan kepuasan bagi pihak yang bersengketa melalui hasil win-win solution.

Harapan ideal tersebut tampaknya masih menjadi impian Mahkamah Agung karena hasil beberapa penelitian menunjukkan bahwa keberhasilan mediasi di pengadilan tidak lebih dari 3\% dari jumlah perkara yang terdaftar. Belum efektifnya mediasi sebagai instrument sistem beracara di pengadilan disebabkan karena faktor substansi, faktor struktur, dan faktor budaya. Ketiga faktor ini harus menjadi perhatian bagi institusi, lembaga terkait, dan masyarakat yang turut serta ikut menentukan kesuksesan mediasi di pengadilan.[a]

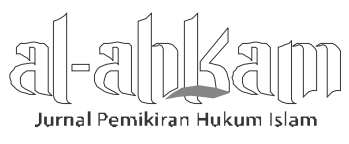




\section{DAFTAR PUSTAKA}

Hasan, Ahmad, "Penyelesaian Sengketa Melalui Upaya (Non Litigasi) Menurut Peraturan Perundang-undangan", Jurnal al-Banjari, Vol. 5 No. 9, Januari Juni 2007.

Muchyiddin, Ali, "Mediasi Sebagai Upaya Penyelesaian Sengketa di Luar Pengadilan", Tesis pada Pascasarjana IAIN Walisongo, 2006.

Manan, Bagir, Sistem Peradilan Berwibawa, Yogyakarta: FH UII Press, 2005.

PerMA No. 2 Tahun 2003 tentang Prosedur Mediasi di Pengadilan Mahkamah Agung Republik Indonesia

PerMA No. 1 Tahun 2008 tentang Prosedur Mediasi di Pengadilan Mahkamah Agung Republik Indonesia

Salamah, Yayah Yarotul, "Mediasi dalam Proses Beracara di Pengadilan: Studi Mengenai Mediasi di Pengadilan Negeri Proyek Percontohan Mahkamah Agung RI", Disertasi pada Fakultas Hukum Universitas Indonesia, 2009.

Sukadana, I Made, "Mediasi dalam Sistem Peradilan Indonesia untuk Mewujudkan Proses Peradilan Yang Cepat dan Biaya Ringan", Disertasi pada Universitas Brawijaya, 2006.

Syukur, Fatahillah A., Mediasi Yudisial di Indonesia Peluang dan Tantangan dalam memajukan Sistem Peradilan, Bandung: Mandar Maju, 2012.

Y.Witanto D., Hukum Acara Mediasi, Bandung: Alfabeta, 2011. 